\title{
A CHEMICAL STUDY OF UTERINE FLUID AND BLOOD SERUM OF NORMAL COWS DURING THE OESTROUS CYCLE*
}

\author{
R. H. SCHULTZ, $\uparrow$ M. L. FAHNING $\dagger$ AND E. F. GRAHAM \\ Department of Animal Science, University of Minnesota, \\ St Paul, Minnesota 55101, U.S.A.
}

(Received 8th December 1970)

\begin{abstract}
Summary. Chemical analyses were conducted on uterine fluid and blood serum collected from eighty-eight normal adult dairy cows during various days of the oestrous cycle. Uterine fluid contained higher concentrations of reducing substances, potassium, inorganic phosphate and alkaline and acid phosphatase activity than blood serum while levels of calcium and sodium were higher in blood serum than in uterine fluid, supporting the concept that bovine uterine fluid is a product of active secretion and not of simple diffusion from the blood. Concentrations of reducing substances, total protein, potassium, chloride, inorganic phosphate and alkaline and acid phosphatase activity in bovine uterine fluid were all found to vary with the stage of the oestrous cycle, indicating that, in the case of these substances at least, secretion into the uterine lumen is under hormonal control. The level of alkaline phosphatase in the blood serum was also found to vary with the stage of the oestrous cycle.
\end{abstract}

\section{INTRODUGTION}

Although the importance of the fluids within the female reproductive tract is well recognized, there is more speculation than proof concerning their rôle in reproductive processes. The relatively few early studies concerned with source, composition and function of uterine fluids have been well reviewed by Amoroso (1952). In recent years, there has been an increasing interest in defining the biochemical nature of the intraluminal environment of the bovine female reproductive tract though efforts to this end have been hindered by the small quantities of fluid available and the difficulty in obtaining the fluid. Olds \& VanDemark (1957a, b) reported results of chemical analyses of uterine fluids recovered from cows following slaughter. Heap (1962) and Heap \& Lamming (1962) subjected uterine flushings taken from live cows at various stages of the oestrous cycle to chemical analyses. Fahning, Schultz \& Graham (1967) reported a study comparing levels of free amino acids in uterine fluids and blood serum collected from cows during the oestrous cycle. In these recent studies, evidence was presented to indicate that the chemical composition of

* Scientific Journal Series, Paper No. 7408, Minnesota Agricultural Experiment Station, St Paul. $\dagger$ Present address: Department of Veterinary Obstetrics and Gynecology, College of Veterinary Medicine, University of Minnesota, St Paul, Minnesota 55101, U.S.A. 
uterine fluid varies with the stage of the oestrous cycle. The purpose of the present study was to compare the concentrations of various chemical constituents in uterine fluid and blood serum in cows throughout the oestrous cycle.

\section{MATERIALS AND METHODS}

Eighty-eight adult, reproductively normal, Holstein-Friesian cows, maintained under normal feeding and management conditions, were used. All had produced at least one normal calf and had calved normally at least 30 days before the collection of uterine fluid and blood serum. All were clinically normal as determined by rectal palpation at the time of sampling. Uterine fluid and blood serum were collected from cows on all days of the oestrous cycle.

Uterine fluid was collected using the technique described by Fahning, Schultz \& Graham (1966). Immediately following collection, the uterine fluid samples were centrifuged at $3300 \mathrm{~g}$ for $10 \mathrm{~min}$ to remove cellular débris. The supernate was transferred into storage vials, identified and stored in liquid nitrogen at $-196^{\circ} \mathrm{C}$ until the analyses were made. At the time of uterine fluid collection, a $20-\mathrm{ml}$ sample of blood was collected from the same animals by jugular venipuncture, allowed to clot and the serum separated by centrifugation at $3300 \mathrm{~g}$ for $12 \mathrm{~min}$. The serum was collected and stored in the same manner as the uterine fluid. Analyses were not conducted until all samples used in the study were collected. As far as possible, constant conditions of collection, storage and handling were maintained for all uterine fluid and blood serum samples.

Chemical analyses of the uterine fluid and blood serum samples were conducted on individual samples using standard methods as adapted for use with the AutoAnalyzer (Technicon Instruments Corp., Chauncey, New York). The concentration of reducing substances was determined using the technique of Hoffman (1937). The modification of the biuret reaction published by Weichselbaum (1946) and adapted for the AutoAnalyzer by Stevens (1963) was used for determination of total protein. Sodium and potassium concentrations were obtained simultaneously using flame photometry with lithium as the internal standard. The method of Zall, Fisher \& Garner (1956) was used for chloride determinations. Calcium was determined using the Kessler \& Wolfman (1964) method. The method of Fisk \& Subbarow (1925), modified for automated equipment, was employed for inorganic phosphate. Alkaline and acid phosphatase activity was measured using the method described by Kind \& King (1954) as adapted for automated equipment by Marsh, Fingerhut \& Kirsch (1959).

Analysis of variance (Snedecor, 1956) was employed to examine the statistical differences of the chemical constituents in the uterine fluid and blood serum between days of the oestrous cycle. Calculations were made to determine the type of regression curve that the data most closely fit. Only data that followed the quadratic regression curve with a level of significance of $P<0.01$ are presented (Text-figs. 1 to 9 ).

\section{RESULTS}

Volumes of uterine fluid collected on the different days of the oestrous cycle are shown in Table 1. An overall average volume of $2.9 \mathrm{ml}$ of uterine fluid was 


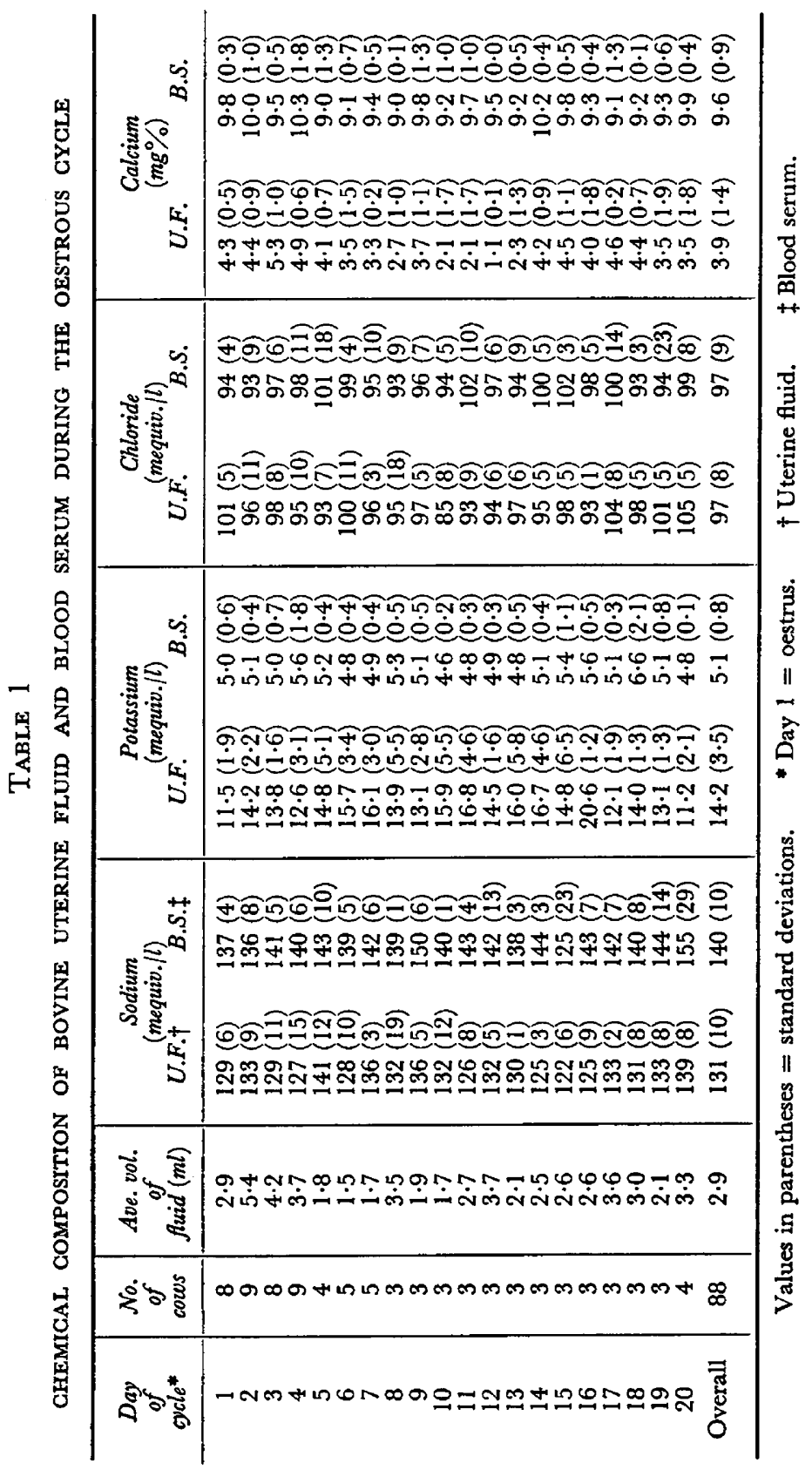


obtained. The greatest volumes of uterine fluid were collected on Days 2, 3 and 4 of the oestrous cycle. The period between Days 5 and 10 of the oestrous cycle was the least productive in terms of volumes collected. The uterine fluid samples collected were serous in nature and there was apparently no increase in viscosity during any particular period of the cycle. Although some blood clots were present in the fluid collected on Days 2, 3 and 4, at no time during the cycle was the fluid itself observed to possess clotting tendencies. As expected, the samples collected during metoestrus were consistently found to be red and brownish-red with blood elements present. Other than during this period, no particular colour of the fluids characterized any phase of the oestrous cycle.

The average values and standard deviations for the volume, sodium, potassium, chloride and calcium concentrations of the uterine fluid and blood serum collected throughout the oestrous cycle are shown in Table 1. Sodium levels

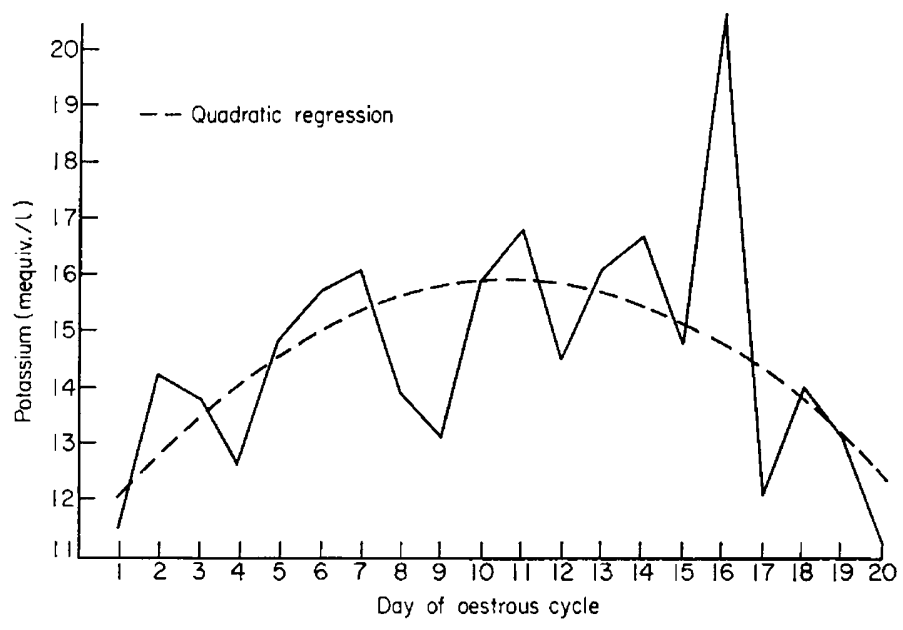

Text-Fig. 1. Potassium content of bovine uterine fluids during the oestrous cycle.

in the uterine fluid and blood serum samples averaged $131^{\circ}$ and 140 mequiv./l, respectively. No significant differences were found between sodium levels in blood serum and uterine fluid. Neither the uterine fluid nor the blood serum concentrations of sodium were found to vary significantly with the stage of the oestrous cycle. The mean potassium concentration in the uterine fluid and blood serum was $14 \cdot 2$ and $5 \cdot 1$ mequiv. $/ 1$, respectively (Table 1 ). The difference between uterine fluid and blood serum potassium content was significantly different. The potassium levels in uterine fluid were significantly associated with the stage of the oestrous cycle (Text-fig. 1).

The overall averages for chloride in both uterine fluid and blood serum were 97 mequiv./1. Although the ranges were similar, only the levels in uterine fluid were found to vary significantly with the stage of the oestrous cycle (Text-fig. 2 ), the lowest levels being found during the luteal phase of the cycle. Calcium was found to be present in significantly lower concentrations in uterine fluid than in blood serum with an average of 3.9 and $9.6 \mathrm{mg} \%$, respectively (Table 1 ). 


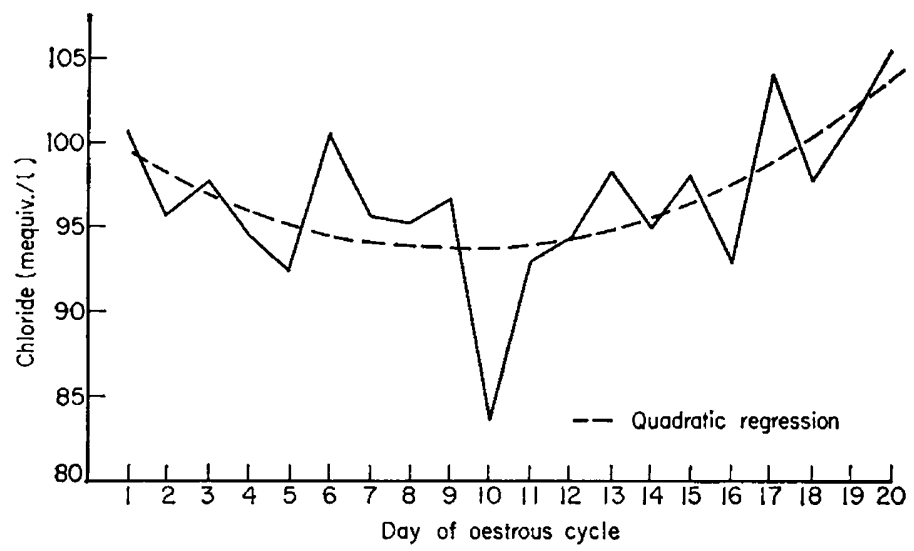

TEXr-FIG. 2. Chloride content of bovine uterine fluids during the oestrous cycle.

The calcium levels in the uterine fluid, but not in the blood serum, were significantly associated with the stage of the oestrous cycle (Text-fig. 3 ).

The mean values and standard deviations of inorganic phosphate found in uterine fluid and blood serum samples are given in Table 2. It can be seen that inorganic phosphate was significantly more concentrated in the uterine fluid than in blood serum. Uterine fluid values averaged $17.9 \mathrm{mg} \%$ while blood serum values averaged $6.1 \mathrm{mg} \%$. The values for uterine fluid were found to vary significantly with the stage of the oestrous cycle (Text-fig. 4) while the blood serum levels did not. The levels in the uterine fluid were highest during the late metoestrous period of the cycle.

Reducing substances and total protein in uterine fluid (Text-figs. 5 and 6) were also found to be significantly associated with the stage of the oestrous cycle. Reducing substances, however, were lowest during early mid-cycle while the opposite was true for total protein. Values for these constituents in uterine fluid and blood serum are listed in Table 2. A significant difference was found

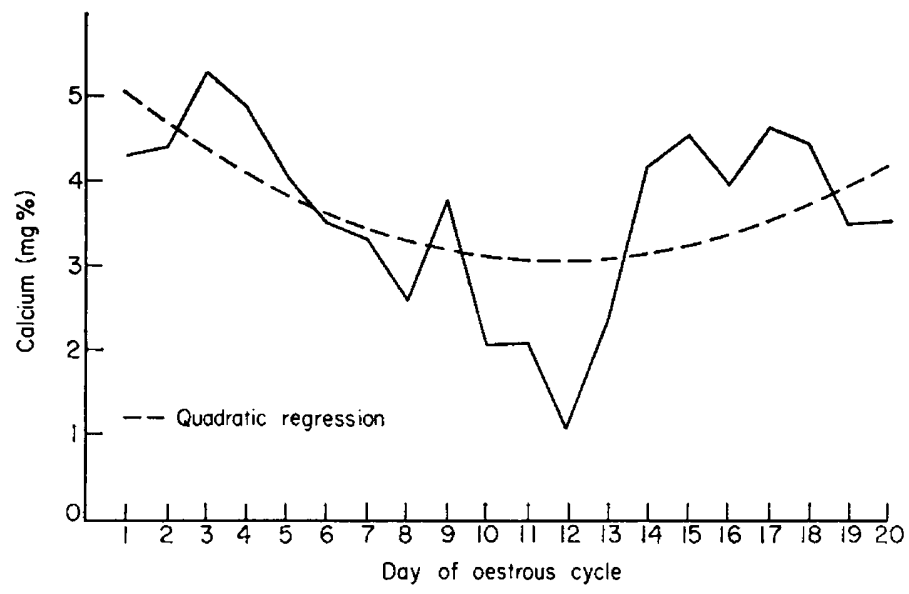

TExT-FIG. 3. Calcium content of bovine uterine fluids during the oestrous cycle. 


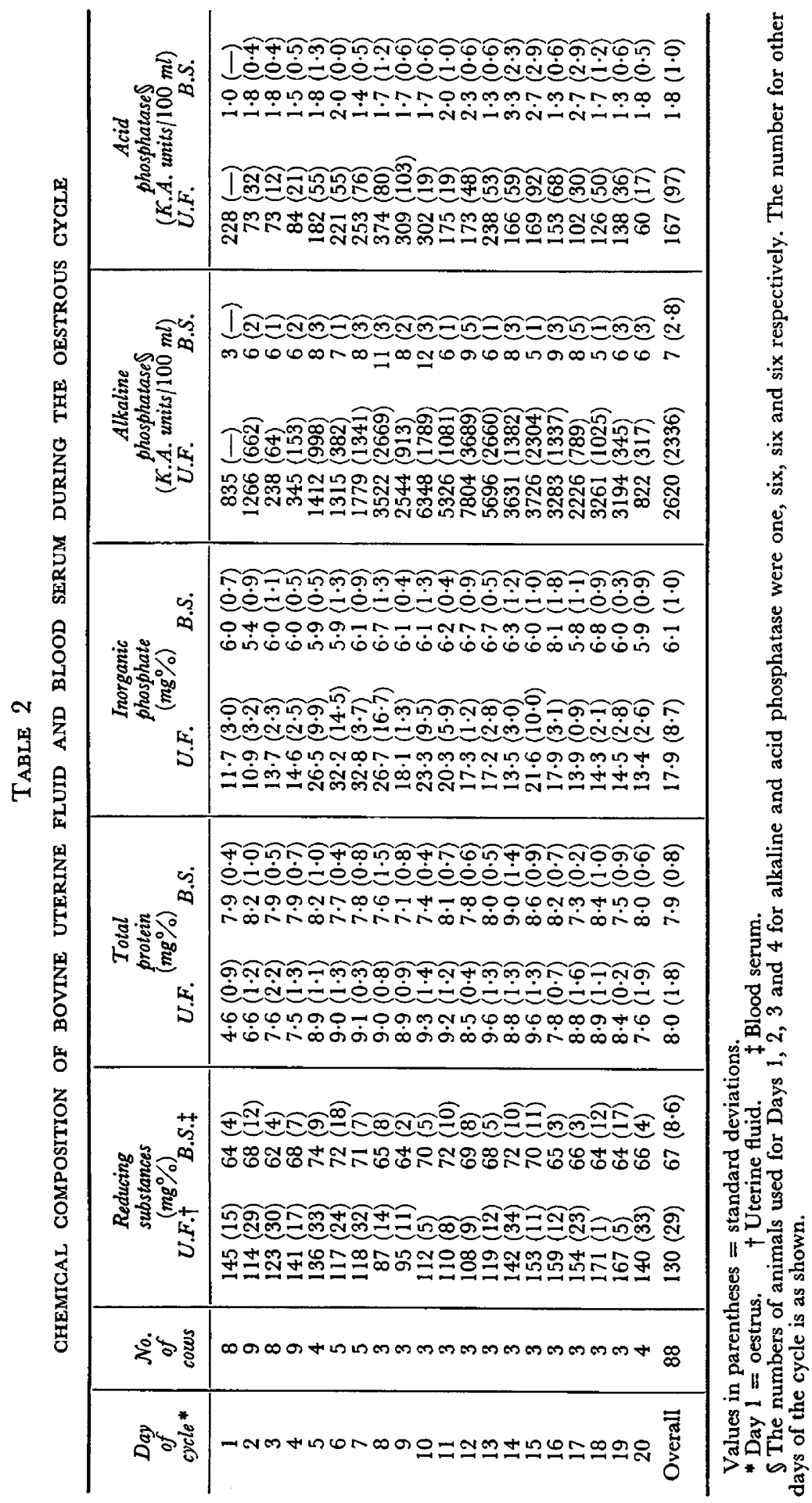


between blood serum and uterine fluid for reducing substances but not for total protein.

The most surprising findings were the large differences in alkaline and acid phosphatase activity between uterine fluid and blood serum (Table 2).

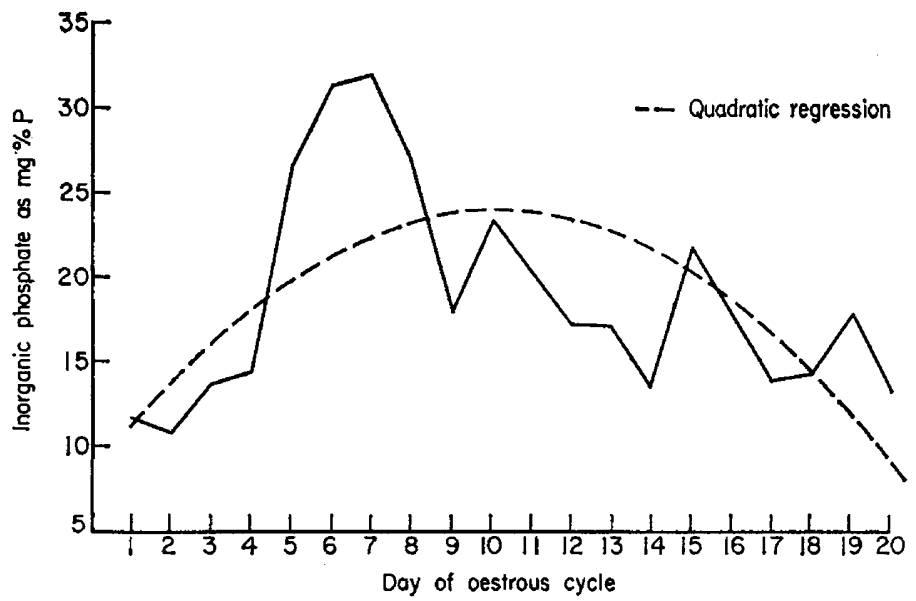

TEXT-FIG. 4. Inorganic phosphate content of bovine uterine fluids during the oestrous cycle.

Alkaline phosphatase activity was particularly high in uterine fluid with daily mean values averaging $2620 \mathrm{King}$-Armstrong units/100 $\mathrm{ml}$ and ranging between 328 and $7805 \mathrm{King}$-Armstrong units $/ 100 \mathrm{ml}$. On the other hand, in blood serum, an average of only 7 King-Armstrong units/100 ml was found.

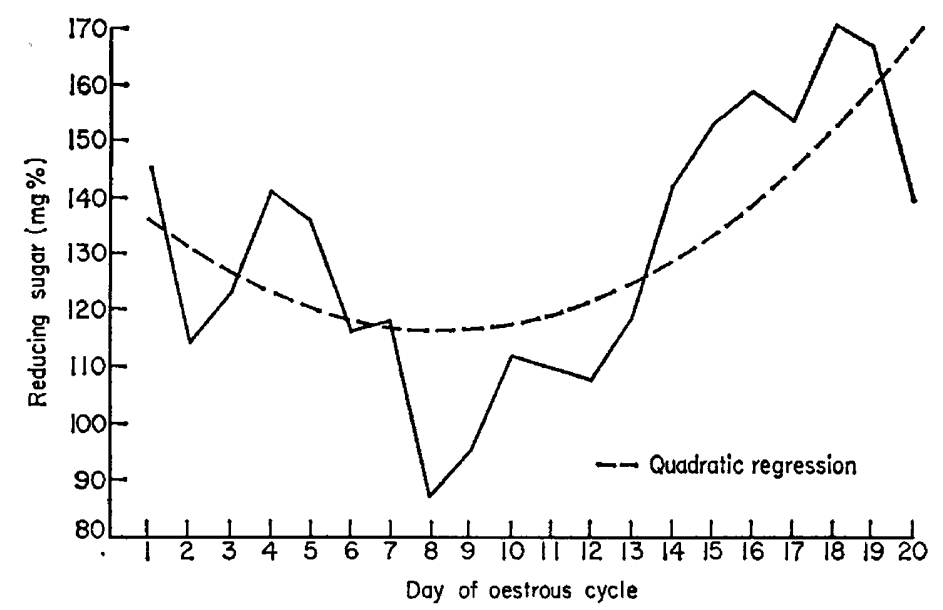

TEXT-FIG. 5. Reducing sugar content of bovine uterine fluids during the oestrous cycle.

Daily mean values of acid phosphatase activity in uterine fluid ranged between 60 and $374 \mathrm{King}$-Armstrong units/100 ml with an average value of $167 \mathrm{King}$ Armstrong units $/ 100 \mathrm{ml}$. Blood serum levels were quite low, averaging only $1.8 \mathrm{King}$-Armstrong units $/ 100 \mathrm{ml}$. Both acid (Text-fig. 7) and alkaline (Text- 


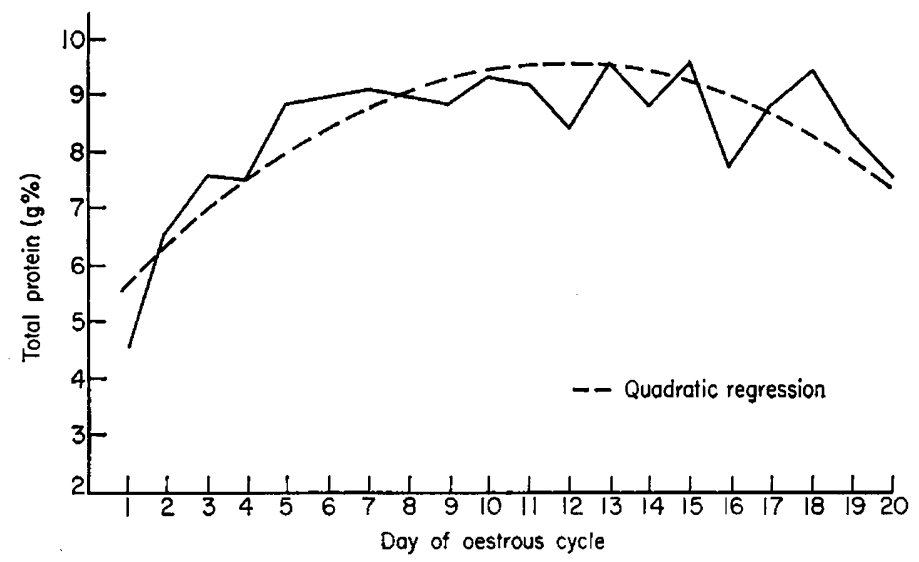

TEXT-Fic. 6. Total protein content of bovine uterine fluids during the oestrous cycle.

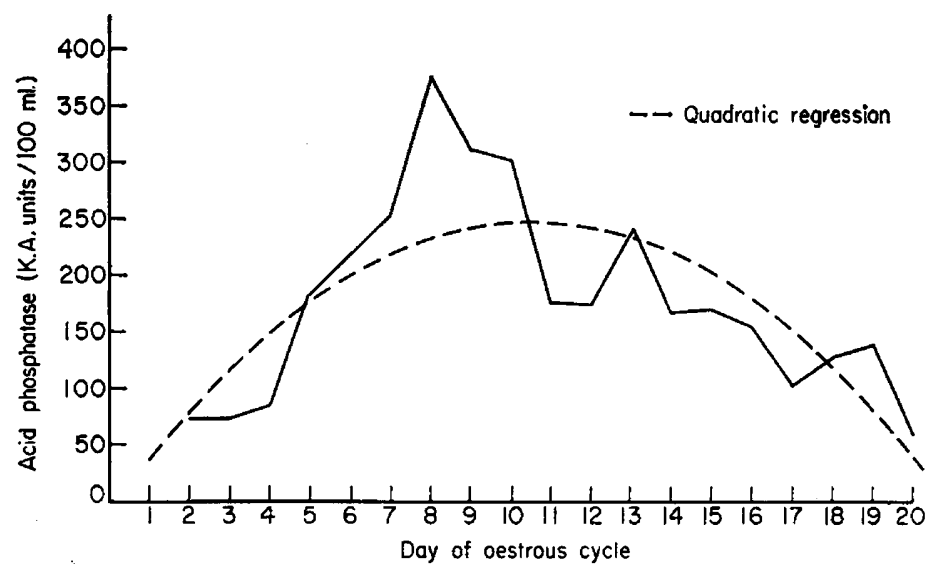

Text-prc. 7. Acid phosphatase content of bovine uterine fluids during the oestrous cycle.

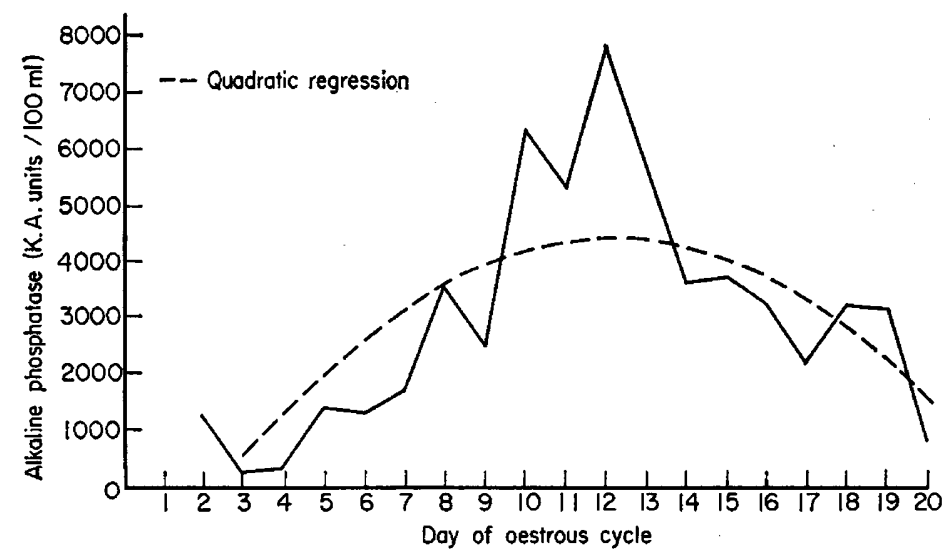

TexT-Fio. 8. Alkaline phosphatase content of bovine uterine fluids during the oestrous cycle. 
fig. 8) phosphatase activity in uterine fluid varied significantly with the stage of the oestrous cycle, the peak values of both being found during the luteal stage of the cycle. The peak values of acid phosphatase occurred somewhat earlier in the luteal phase than that of alkaline phosphatase. Alkaline phosphatase activity in blood serum, although considerably lower than in uterine fluid, was also found to vary significantly with the oestrous cycle (Text-fig. 9). Such was not the case with acid phosphatase.

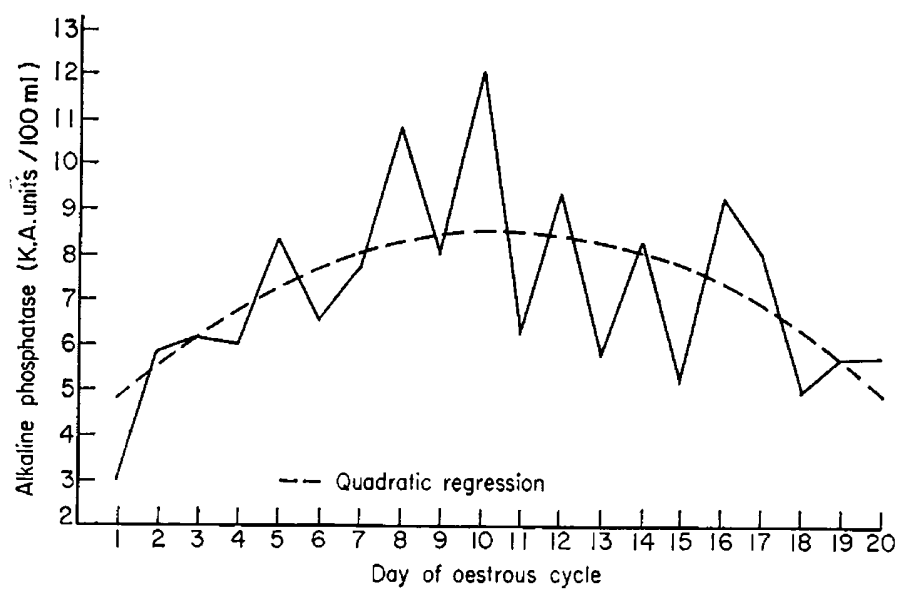

TEXT-FIG. 9. Alkaline phosphatase content of bovine blood serum during the oestrous cycle.

\section{DISCUSSION}

The volumes of fluid collected from each horn of the uterus were not considered to be absolute volumes. Accordingly, the quantities of chemical constituents determined in this study were not considered as absolute values, but concentration changes. Although difficult to measure quantitatively, there were various factors found to affect the volume of fluids obtained at each collection attempt. These included differences in size of uterine horns (both between cows and between horns within cows) and the degree of relaxation of the rectal wall allowing ease in manipulation of the reproductive tract.

The greatest amount of fluid was collected at or near the time of oestrus. Although larger quantities of fluid were obtained between Days 2 to 4 of the oestrous cycle, no striking pattern in volume collected was found. In general, quantities obtained were lower during the luteal phase than during the preand immediate postoestrous phase of the cycle. This was consistent with the findings of Olds \& VanDemark (1957a). The increased viscosity of the fluid during the period from Day 11 to Day 20 reported by Olds \& VanDemark (1957a) was not found in this study. The fluids collected were serous at all times during the oestrous cycle. 
The levels of sodium and potassium found in uterine fluid were lower than those reported by Gupta (1962). It is difficult to make a direct comparison between these results, however, since, in the present study, particular effort was made to prevent contamination of the uterine fluids with cervical fluid and it is not clear in Gupta's work whether the fluid analysed was uterine fluid only, or a combination of uterine and cervical fluid. Olds \& VanDemark (1957a, b) reported slightly lower sodium levels and higher potassium levels in fluids collected from uteri of slaughtered cows than were found in the present study. The results of electrolyte determinations in slaughterhouse material must be questioned in the light of the findings of Howard \& DeFeo (1959) using swine, and Heap (1962) using sheep. Both studies illustrated the fact that ion and water shifts between intra- and extracellular spaces tended to negate the value of using slaughterhouse material. Howard \& DeFeo (1959) found that sodium levels increased at the expense of potassium levels in the uterine fluids they studied. This was not the case in the present study.

The high concentration of potassium found on Day 16 of the oestrous cycle is difficult to explain. In the light of the low standard deviation, the effect was not due to a large variation in one individual animal. Since other constituents did not demonstrate a similar rise on the same day and since the samples were analysed in random sequence, it is difficult to attribute the rise to technical analytical errors. Any significance ascribed to this rise would be mere conjecture.

There was greater variation found in potassium concentrations in uterine fluid than in blood serum (Table 1). Uterine fluids are composed of secretions of endometrial glands and cellular detritus. Differences in the number of degenerating cells present in the uterus would thus be expected to result in a significant variation in potassium levels between cows.

The observation that calcium concentrations in uterine fluid were lower than blood serum calcium levels is consistent with the results reported by Olds \& VanDemark (1957a, b) and Gupta (1962). Heap (1962) and Heap \& Lamming $(1960,1961)$ found only traces of calcium in the uterine flushings they collected from the cow during either the luteal phase or the follicular phase of the oestrous cycle. Gupta, as well as Olds \& VanDemark, reported calcium levels in the uterine fluid higher than those found in the present study. This was probably due to the differences in the collection techniques employed. The finding that calcium in the uterine fluid was higher near to and during oestrus than during the luteal phase of the cycle agrees with the report of Olds \& VanDemark $(1957 \mathrm{a}, \mathrm{b})$.

From Table 1, it can be seen that there was a high potassium : calcium ratio in the uterine fluids. This was highest during the luteal phase of the oestrous cycle. In the light of the reports of Kaufman \& Laskowski (1931) and Yoshiura (1932), this might serve as an indication of growth potential for the blastocyst in the intrauterine environment, particularly when under the progestational influence.

The concentration of inorganic phosphorus found in the uterine fluid of cows was higher than that reported in the studies by Olds \& VanDemark (1957a, b) and Gupta (1962). In all three studies, however, the uterine fluid concentration 
was higher than in blood serum. The opposite was found to be the case for the rat, rabbit and dog (Shih, Kennedy \& Huggins, 1940).

Reducing substances in the uterine fluids were approximately twice as high as the overall mean value for blood serum reducing substances. This is the reverse of the findings reported by Olds \& VanDemark (1957a, b), which were considerably lower. They were using slaughterhouse material, however, and it has been shown by Heap (1962) that the carbohydrate content in sheep uterine fluids collected following slaughter was appreciably lower than when the fluids were collected by laparotomy and flushing from anaesthetized ewes. The results are also not in agreement with the work of Olds \& VanDemark (1957a, b) or Heap (1962) in that their studies indicate that reducing substances and carbohydrates are highest during the luteal phase of the oestrous cycle. It is uncertain whether the differences in the means of collection are sufficient to account for this variation.

No characterization of the proteins present was made. The levels of proteins found were somewhat higher than those found in previous studies, though the methods of collection may well account for this difference.

Alkaline and acid phosphatase activity was highest in the uterine fluid during the luteal phase of the oestrous cycle though there was considerable variation between cows. Histochemical investigations of the endometrial tissue of the cow have indicated that alkaline phosphatase activity levels vary with the stage of the oestrous cycle (Moss, Wrenn \& Sykes, 1954; Skjerven, 1956) but the magnitude of the activity found was unexpected. In contrast to the situation in the pig (Akins, Morrissette \& Cardeilhac, 1969), peaks in both the acid and alkaline phosphatase activity occurred during the luteal phase of the cycle. Although the acid phosphatase activity peak occurred earlier than the alkaline phosphatase peak, indicating that the acid phosphatase activity was not merely a reflection of the very high alkaline phosphatase activity, the biological significance of this is mere speculation at the present time. The relationship of both acid and alkaline phosphatase activity to the stage of the oestrous cycle compares closely with the histochemical determinations of the same enzymes in the endometrium found by Kenney (1964). Although many functions, such as providing inorganic phosphate ions for metabolic, secretory or excretory functions, have been attributed to the phosphatases in biological systems, the rôle of these enzymes in the uterine fluids has not been determined.

The findings of this study support the fact that the composition of the fluids within the uterus of the cow is a result of active secretion and not merely a product of diffusion from the blood. This was further supported by the findings of Fahning et al. (1967) in which the concentrations of free amino acids in the uterine fluids were found to be significantly different from those in the blood serum of cows. The mechanism controlling this active secretion is yet to be determined.

That the composition of the uterine fluid in the cow is under the control of hormones was illustrated by the fact that concentrations of reducing substances, total protein, potassium, chloride, inorganic phosphate, and alkaline and acid phosphatase activities all varied significantly with the stage of the oestrous cycle. The greatest variation was found to occur in the period of 
metoestrus. Since this is the period when the early embryo is entering the uterus, it would be of interest to study this period of the cycle more fully in relation to early embryonic requirements and in relation to the 'repeat breeder' cow syndrome. Cannulation techniques are being investigated for this purpose.

\section{ACKNOWLEDGMENTS}

The authors wish to thank the Louis W. and Maude Hill Family Foundation for their financial support of this project. The work was also supported in part by USPHS Research Fellowship No. 5-F2-GM-15,000, for which gratitude is expressed. The authors appreciate the opportunity for the use of cows in the Minnesota State Institutional and Experiment Station Herds for this study.

\section{REFERENCES}

Akins, E. L., Morrissette, M. C. \& Cardeilhac, P. T. (1969) Luteal and endometrial phosphatase activities during the porcine estrous cycle. $\mathcal{7}$. Anim. Sci. 28, 51 .

Amoroso, E. C. (1952) Placentation. In: Marshall's Physiology of Reproduction, Vol. II, p. 127. Ed. A. S. Parkes. Longmans, London.

Fahning, M. L., Schultz, R. H. \& Graham, E. F. (1966) A technique for the collection of uterine fluids from the live cow. Vet. Rec. 79, 230.

Fahning, M. L., Schultz, R. H. \& Graham, E. F. (1967) The free amino acid content of uterine fluids and blood serum in the cow. J. Reprod. Fert. 13, 229.

Fisk, C. H. \& Subbarow, Y. (1925) The colorimetric determination of phosphorus. F. biol. Chem. 66, 375.

Gupta, H. C. (1962) Biochemical and physiological properties of cervical and uterine fluids of the cow during estrus. Diss. Abstr. 23, 803.

HEap, R. B. (1962) Some chemical constituents of uterine washings: a method of analysis with results from various species. F. Endocr. 24, 367.

HEAP, R. B. \& LAMMING, G. E. (1960) Studies of the uterine environment of different species. I. Influence of ovarian hormones on the chemical composition of uterine secretions. F. Endocr. 20, 23.

Heap, R. B. \& Lamming, G. E. (1961) Studies of the uterine secretion of different species. Proc. IVth Int. Congr. Anim. Reprod., The Hague, p. 300.

HeAp, R. B. \& Lamming, G. E. (1962) The influence of ovarian hormones on some chemical constituents of the uterine washing of rat and rabbit. F. Endocr. 25, 57.

Hofrman, W. S. (1937) A rapid photoelectric method for the determination of glucose in blood and uterine. F. biol. Chem. 120, 51.

Howard, E. \& DeFeo, V. J. (1959) Potassium and sodium content of uterine and seminal vesicle secretions. Am. F. Physiol. 196, 65.

Kaufman, L. \& Laskowski, M. (1931) Rate of growth and the K-Ca ratio. Biochem. 7. 242, 424.

KENNEY, R. M. (1964) Histochemical and biochemical correlates of the estrous cycle in the normal cycle uterus and ovary of the cow. Diss. Abstr. 64, 13780.

Kessler, G. \& Wolfman, M. (1964) An automatic procedure for the simultaneous determination of calcium and phosphorous. Clin. Chem. 10, 686 .

KIND, P. R. N. \& KING, E. J. (1954) Estimation of plasma phosphatase by determination by hydrolysed phenol with amino-antipyrine. F. clin. Path. 7, 322.

Marsh, W. H., Fingerhut, B. \& Kirsch, E. (1959) Adaptation of an alkaline phosphatase method for automatic colorimetric analysis. Clin. Chem. 5, 119.

Moss, S., WRenN, T. R. \& Syxes, F. F. (1954) Alkaline phosphatase, glycogen and periodic acid-Schiff positive substances in the bovine uterus during the estrous cycle. Endocrinology, 55, 261.

Olds, D. M. \& VanDemark, N. L. (1957a) Composition of luminal fluids in bovine female genitalia. Fert. Steril. 8, 345.

Olds, D. M. \& VanDemark, N. L. (1957b) Luminal fluids of bovine female genitalia. 7. Am. vet. med. Ass. 131, 555.

Shit, H. E., Kennedy, J. \& Huggrns, C. (1940) Chemical composition of uterine secretions. Am. F. Physiol. 130, 287.

Skjerven, O. (1956) Endometrial biopsy studies in reproductively normal cattle. Acta endocr., Copenh. Suppl. 26, 134. 
SNedecor, G. W. (1956) Statistical methods, 5th edn. Iowa State College Press, Ames, Iowa.

Stevens, D. L. (1963) Total protein determination, general description. In: AutoAnalyzer Methodology (N-14a). Technicon Instruments Corp., Chauncey, New York.

Weichselbaum, T. E. (1946) An accurate and rapid method for the determination of proteins in small amounts of blood serum and plasma. Am. 7. clin. Path. 7, 40.

Yoshura, H. (1932) Biology of pregnancy. Potassium-calcium ratio in muscle and liver and its relationship to growth processes. Arch. Gynaek. 152, 89.

Zale, D. M., Fisher, D. \& Garner, M. O. (1956) Photometric determination of chlorides in water. Analyt. Chem. 28, 1665. 